\title{
The Weight of History: Germany's Military and Domestic Security
}

\author{
Col. Gerhard J. Klose*
}

\section{Introduction}

In order to arrive at a correct understanding of the German attitude towards homeland security, homeland defense, or military involvement in domestic operations, it is important to know that Germans think of their Bundeswehr as an institution designed for nothing else but to guarantee homeland defense and security. The defense of the German homeland has always been the main task of the German armed forces. And, through most of Germany's history, providing homeland security and defense has taken place as a domestic operation. Situated at the center of Europe and being nearly completely surrounded by potential enemies, there were always only two options for Germany in conducting this defense of its soil: to make it happen either inside or outside of the homeland.

For centuries, Germany was prepared to use its terrain as the battlefield for homeland defense. This became especially true during the Cold War, when German territory was accepted as the theatre for the main ground conflict of a potential Third World War. It was also accepted that Germany was very likely to be affected by nuclear weapons in the event that World War III erupted. During the forty-five years of the Cold War, Germany got used to the idea of limiting its defensive actions to its own territory. There were never official plans in place to cross borders and take steps for the defense of the homeland outside Germany's borders, as in former days.

This understanding of homeland defense is still valid for most Germans. However, the fact that traditional military forces no longer threaten German territory has not yet supplanted the old understanding of homeland defense - not even among soldiers. In addition, the majority of the German population does not identify the new threat from international terrorism as a potential military threat. So the mental and legal framework for the military activities of the German armed forces on domestic soil is still founded on the two old basic notions: the presence or the absence of a conventional military threat, and an attack on German territory. Thus there is a clear distinction between the two legal states of war or peace in Germany, states that are determined by the German Parliament.

The legal framework that is in place to meet the requirements of these two basic situations still appears valid to most Germans. German society will probably stick to this simple black-and-white picture as long as there is not a huge failure resulting from this approach.

* Colonel (GS) (ret) Gerhard Klose (German Army) served as the principal staff officer for domestic operations on the Joint Staff of the German Armed Forces. He has extensive joint and NATO operational experience. 
The U.S. approach to homeland security appears completely different. There has never been a serious threat to the territory of the U.S., at least not by conventional land forces. Therefore, their response to the new global security environment is different. In Germany, the problem is to change a system that everyone has become used to over the years, and that has apparently worked well so far.

There is a second peculiarity in the German situation. After World War II and the defeat of the Nazi regime, there was a complete revision of German society, the entire political system and, as a part of that, the armed forces. This new start, which began during the Allied occupation of Germany after the war, included strict restrictions on the exercise of political power. Understandably, a first priority was to prevent Germany from becoming so powerful and dangerous again.

There was also a second effect. The German politicians that were assigned the task of creating the new legal-political framework had a strong desire to eliminate all possibilities of the abuse of central political and military power. Most of the authors of the constitution themselves had suffered severely under the Nazi system. Taking as their guiding maxim "It shall never happen again," it was inevitable that there would be compromises in the new political system.

The historical background to the constitution shaped the legal framework for both the foundation of the new German democracy and its military forces. In order to understand the limitations of the existing system and the scope for its future development, it is essential to recognize this fact.

\section{The Historical Background of the German Constitution: The Basic Law}

After World War II, Germany was completely under the authority of the four occupying Allied Powers. The road back to full sovereignty proved to be long and arduous. It was not until 1992, in the course of the reunification of East and West Germany, that Germany regained its full sovereignty.

The level of mistrust of Germany in 1945 was great, and easily understandable. So the first steps back towards self-administration were made from the bottom up, following the principle "divide and conquer." Beginning with regaining local and regional self-administration, the first major step towards future independence came with the reestablishment of the German States, the Bundesländer. These states, however, produced different and independent laws and regulations, very much depending on the individual Allied Power in charge of that region. The differences between the Bundesländer that were established in those early days still exist today. It can be compared with the independence of the different states of the U.S.; in fact, their example might have influenced the development of the diversity of law in the German states. There are two important differences in the German case, however. First, most of the Bundesländer are much smaller than the states in the U.S. Second, Germany had already experienced the greater effectiveness of a more centralized political and administrative system, a historical situation that was never present in the early United States.

It was not until 1949 that the three Western Allies decided to put their administrative zones together and form a union out of these states. The constitution for this newly 
created union, the Federal Republic of Germany, had to be of a somewhat preliminary and provisional nature, of course, as the possibility of reunion with the eastern part of Germany could not be excluded. As much power as possible stayed with the individual states. This is still the case today, with all the well-known disadvantages that result when dealing with matters that would benefit from central coordination.

It was not the sole intention of the victors of World War II to prevent Germany from becoming dangerous once again. The vast majority of German society, represented by the authors of the constitution, also had the same strong desire to never let fascism and militarism rise again in Germany. Strong governmental centralization had been an excellent defense for both phenomena in the pre-war years. Therefore, precautions against the possible misuse of central power were sometimes favored over the effectiveness or efficiency of public administration.

These general principles are still in effect today, and make actions difficult in situations where centralized governmental management would be essential-e.g., in planning domestic defense against international terrorism.

There is a second effect that should also be taken into account before trying to understand the German military system. When the new constitution came into effect in 1949, there was no intention to ever have German military forces again at all. Germany was still strongly committed to de-militarization and de-nationalization. This led into a broader current of pacifism. To have no military at all was thought to be the safest way to ensure that the excesses and abuses of the fascist era never took place again. So, when it was finally decided to once again have a military, the constitution had to be substantially rewritten, which faced intense resistance. Because of this strong opposition from the German population and an important part of the political elites, the legal framework for the German armed forces was carefully crafted to prevent the forces from being used against the civil population by the central government. The German constitution is therefore very clear and strict about how the armed forces can be used. This is especially evident when it comes to actions other than fighting against unambiguously identified combatants. Once again, optimum effectiveness was not the first priority, but rather the prevention of potential abuse.

Even though the legal framework governing the formation and use of the German armed forces has been amended from time to time, particularly when it proved to be impracticable in essential areas, the restriction on the use of military power has remained a dominant attitude to this day. So the constitution clearly restricts the armed forces to engagement only for purposes of defense. In Article 87a, it states in paragraph 1: "The Federation establishes forces for defense...." The following paragraph states, "Apart from defense, the forces may only be employed in ways explicitly allowed by this Basic Law."

In addition - and in this way it differs from other nations - Germany's constitution has the quality of law, a superior law. It might therefore be called a Grundgesetz (Basic 
Law $^{1}$ ), and not a Verfassung (Constitution). The Basic Law does not solely bind the processes of legislation and jurisdiction, but is also applicable to every individual citizen. Laws that are found to be in conflict with the Basic Law will automatically be overruled. A special Court of Constitution (Bundesverfassungsgericht) exists, where affairs with a constitutional dimension will get a final interpretation. The sentences of the Court of Constitution bind the government and the parliament. There are many cases where laws that had passed both chambers of parliament had to be repealed and reworked under clear restrictions established by the Court of Constitution.

Moreover, the legal framework for and the structure of the new German armed forces, the Bundeswehr, were intentionally designed to make them as different from those of the former Wehrmacht as possible. Once again, operational effectiveness was not the first priority.

With the German armed forces being limited to the defense of their home territory, all these limitations on a more effective engagement model seemed to be acceptable. And the resulting system proved to work quite well under the unique circumstances of the Cold War. However, forty years of experience for the Bundeswehr in this mode have created attitudes that may have to some extent become entrenched.

After the terrorist attacks of recent years, Germany, like all other nations, is confronted with a completely new threat, in a completely different security environment. It is questionable whether the new types of threat might successfully be met with the existing capabilities and attitudes of both German society and the German military.

\section{Options for the German Armed Forces to Act in Cases of Defense or Tension}

The German constitution clearly relates the engagement of the armed forces to two different states, with two different sub-states: one is the state of defense or tension; the other is the absence of a state of defense or tension. Under this there are two sub-states: operations against combatants, and operations against non-combatants.

Article $87 \mathrm{a}$ of the Basic Law states in paragraph 3 the options for military engagement against non-combatants: "In the case of defense and tension, the armed forces are allowed to protect civilian property ${ }^{2}$ and to control traffic as far as it is necessary for the completion of their defense mission. Moreover, in times of tension and defense, the armed forces might additionally be tasked to support the police in protecting civilian property. In this case, the forces act in cooperation with the related civilian administration."

Of course, it is hardly necessary to mention that the armed forces are permitted to act militarily with every means allowed by the Geneva Conventions against hostile

To make clear the special quality of the German constitution, the name Basic Law is used for the rest of this essay.

2 The term "civilian property" stands for critical infrastructure. The commentaries are quite clear about the interpretation in this case. As all critical infrastructure is of military interest to an attacking force, it can become a military target. Effective protection requires combatants. 
combatants. But the Basic Law clearly limits the options for actions against non-combatants, even in defense situations.

For example, the protection of civilian property is normally a task of the police forces. Protection by the military is only authorized if a site or structure is of military importance to German forces. Other civilian property, being of no direct military interest to German forces, may only be protected by the military if it is likely to be attacked and is of importance to the enemy (critical infrastructure). Nuclear power plants might fall into this category of property, but military protection would always be limited to attacking combatants. Acting against non-combatants in this case would always have to follow the regional police guidelines, which differ from state to state. That makes the situation more complicated.

The same applies to the control of public movement and traffic. As stated in the Basic Law, traffic may only be controlled as far as the requirements of the defense operation demand. These strict legal limitations, even in cases of homeland defense, very clearly show the attitude and intention of the new German democracy concerning the use of military power against non-combatants in general.

As is laid down in the Basic Law, the same regulations apply in states of defense, as well as in states of tension. Both terms are defined in the Basic Law. Article 115 says everything about the state of defense and how it is declared. Parliament has to approve this step with a two-thirds majority. The Basic Law also states what is to be done when there is not enough time to reach a decision in this way. In essence, it is vital that the state of defense will come into effect as soon as an attack has been launched across the German border.

Contrary to the rather broad definition of the state of defense, the preconditions for declaring a state of tension are not defined at all in the Basic Law, even though it offers the same amount of additional rights to the armed forces as the state of defense. But the commentaries on the Basic Law are unanimously of the opinion that the state of tension describes a phase when it is evident that an attack by combatants is soon to be launched. ${ }^{3}$

In opposition to the unclear definition of the state of tension, Article 80a clearly describes how it is reached. Again, a decision of the parliament is needed, with a majority of two-thirds. However, there is also a second option as to how this status may be achieved-i.e., if an international executive body of a defense alliance (such as NATO) officially states this to be the case. (This exemption was specifically inserted on behalf of NATO obligations.) Such an external decision becomes effective subject to its approval by the federal government. In this case, parliamentary approval is not necessary. But how sensitive the authors of the Basic Law were regarding the legitimization of extra rights for the armed forces becomes evident in a further description in Article $80 \mathrm{a}$, which declares that a state of tension can be terminated at any time by a decision of parliament with a simple majority.

3 See: Bruno Schmidt-Bleibtreu, Kommentar zum Grundgesetz, 10th Edition (Verlag Luchterhand); see also Dieter C. Umbach, Grundgesetz, Mitarbeiterkommentar und Handbuch (Berlin: Deutsche Bibliothek, 2001). 
All the provisions in the Basic Law concerning the armed forces make very clear that they were made exclusively to enable the German armed forces to conduct the defense of German territory, together with the Allies, and for no purposes beyond these. Security against abuse was always the first priority.

It should be noted that nothing from either earlier military traditions or constitutions was included in the Basic Law that would have allowed more latitude regarding the use of military power. It is now evident that the German Basic Law originally was not equipped to handle and regulate threats of the kind that Germany is now facing.

\section{Options for the German Armed Forces to Act in the Absence of a State of Defense or Tension}

Apart from acting under the conditions of the states of defense or tension, there are more options set forth in the Basic Law for the use of military abilities and capabilities in order to support the security of the country.

\section{Military Assistance in Civil Disturbances and Insurrections}

In Article 87a, paragraph 4 of the Basic Law (in conjunction with Article 91), a very sensitive issue is touched on: the situation of internal disturbances and tensions, such as riots. It states:

In order to avert an imminent danger to the existence or to the free democratic basic order of the federation or a state, the federal government may, should the conditions of Article 91 apply, and the police forces and the Federal Border Guard be inadequate, use the armed forces to support the police and the Federal Border Guard in the protection of civilian property and in combating organized and military armed insurgents. Any such use of armed forces must be stopped at parliament's request.

Article 91 reads as follows:

1. In order to avert an imminent danger to the existence or to the free democratic basic order of the federation or a state, a state may request the services of the police forces of other states, or of the forces and facilities of other administrative authorities and of the Federal Border Guard.

2. Should the endangered state not be willing or able to combat the danger, the federal government may place the police forces of other states under its own control and commit units of the Federal Border Guard.

The order for this shall be rescinded after the removal of the danger or else at any time on request of the Senate. ${ }^{4}$

This regulation is clearly intended to address circumstances of great internal unrest, caused by Germany's own citizens. But the rights granted to the central government for

4 The German Parliament has two chambers. The Bundestag, similar to the U.S. House of Representatives, represents the people. It is here referred to as parliament. The Bundesrat, similar to the U.S. Senate, represents the states (Bundesländer). It is here referred to as the senate. 
intervention are limited to cases of unrest so large that they might endanger the existence of the whole federation, a single state, or substantially endanger the basic democratic order of society. Following the commentaries, the authors of the Basic Law were mainly thinking of a form of communist revolution, beginning in one state and then spreading out through the republic. In this case, they wanted special rights for the central government to enable them to re-establish the democratic order. The possibility of military support was granted, but again under very strong limitations:

- The scale of the unrest had to be capable of endangering the existence of at least one of the States;

- The armed forces were only to support the police forces. That meant that, once again, they would have to act not in a military, tactical way, but under the legal conditions applicable to the police force of the relevant state;

- The options of engagement for the armed forces in this case are limited to "protection of civilian property" and "fighting against organized and military armed insurgents." By this provision, the engagement of the armed forces against unarmed people is clearly prohibited;

- Finally, the engagement of the armed forces, when requested by the federal government, can be immediately stopped by the vote of the senate, the parliamentary chamber of the states.

Fortunately, no situation has ever arisen in the Federal Republic of Germany to call this regulation into effect. However, this is not to say that it could not happen in the future. CBRN scenarios could quickly assume such scope that an entire state might be affected, and would no longer be able to manage the situation.

This very special type of engagement for the German armed forces has to be recognized as a core task of the Bundeswehr. Therefore, the costs of such an intervention would have to be covered by the defense budget.

This is quite different from all the other following options. They fall under the legal principle of subsidiarity. That means that interventions of these types - if requestedwould be mandatory, but would have to be executed only using the existing means and capabilities of the armed forces. In addition, the types of engagements discussed below will have to be paid for by the relevant state or the entities receiving support.

\section{Emergency Aid and Rescue Support}

The provision of support in the form of emergency aid and rescue equipment is mentioned here only in order to provide a complete picture of the legal possibilities for the German military's contribution to homeland security.

The provision of emergency aid is an obligation, although it is not directly derived from the Basic Law; rather, it stems from general legal principles. ${ }^{5}$ It is not so much an obligation placed on the armed forces, but rather on each individual citizen. If emer-

See, for example, Strafgesetzbuch der Bundesrepublik Deutschland $\S 34$ (Penal Law of Germany §34). 
gency aid is required to support individuals or private organizations, then any immediately required measures may be engaged for rapid assistance. But this general permission, which has to be ordered by any present military authority, is very much limited by clear conditions ${ }^{6}$ - the aid may involve only a few personnel, single cars, and a minimum of equipment, and may be committed only for a short period of time. No law enforcement functions can be undertaken, and as soon as there is enough civilian support present the military support has to be withdrawn. In addition, the cost for this support must be reimbursed.

The same restrictions apply to the provision of support in the form of rescue equipment. In this case, the armed forces may assist civilian rescue services in accordance with a corresponding regulation, which states that the armed forces may use their rescue equipment to support the civil sector in emergency situations, and may also provide practical training of medical personnel. ${ }^{7}$ Again, no law enforcement operations can be carried out along with this option, and reimbursement is required to the same extent as with civilian rescue services.

If emergency aid is required by the public administration, the case is very different. This is an issue of great importance for the engagement of the German military in homeland security affairs. Such aid is called - literally translated — administration assistance (Amtshilfe). For the following discussion, it will be called "Military Assistance to Civil Authorities" (MACA), in order to keep it close to the language of similar U.S. regulations.

\section{Military Assistance to Civil Authorities (MACA)}

Military Assistance to Civil Authorities (MACA) in Germany is part of the general scope of administration assistance that all parts of the government have to provide for each other, if their own capabilities are exceeded. This obligation is basically described in Article 35 of the Basic Law, and is detailed in a special federal law about the principles of public administration. ${ }^{8}$

Article 35, paragraph 1 of the Basic Law reads as follows: "All administrations of the federation and the states provide mutual assistance in legal and administrative affairs." The special executive law mentioned above gives explanations and elaborates more details. The most important are:

- Support is only granted at the request of a public administration whose own capabilities are exceeded. Permanent mission transfer for regular or recurring obligations is not allowed;

6 Bundesministerium der Verteidigung, Ministerialblatt (VMBl), Hilfeleistungen der Bundeswehr bei Naturkatastrophen bzw besonders schweren Unglücksfällen und dringender Nothilfe (1978), 86.

7 Bundesministerium der Verteidigung, Ministerialblatt 1988, Richtlinie über den Einsatz von Rettungsmitteln der Bundeswehr im Rahmen des zivilen Rettungswesens (1988), 270.

8 Hans Günther Henneke, et al., Verwaltungsverfahrensgesetz, 8th edition Kommentar, § 4-8. 
- The support consists only of the means that the supporting administration has available for its core tasks. So, for the Bundeswehr, it would not be legal to stock special equipment only for cases of administration assistance. That is the first condition of the principle of subsidiarity;

- Support is to be given only to the extent that it does not affect the core task of the supporting administration. That means that necessary military activities would always remain the first priority. ${ }^{9}$ That is the second condition of the principle of subsidiarity;

- The costs of the deployment would have to be reimbursed by the supported administration. This applies only to material costs; no costs for personnel are reimbursed.

Commentaries about the first paragraph of Article 35 are unanimously of the opinion, that this paragraph addresses technical and logistic support only. ${ }^{10}$ Thus, unlimited manpower and/or equipment might be provided by the armed forces, but their participation in law enforcement functions would remain strictly prohibited. On the basis of this paragraph, the German armed forces have until now mainly provided their support only in cases where they came into action in broader homeland security operations, such as disaster relief engagements. In such situations they would not bring any weapons or armaments with them beyond hand-held weapons for guarding and self-defense.

During such a MACA-type mission, the military structure of command and control would remain in action. However, the supporting forces would be put under the direction of the civil authorities as far as the disaster management effort would be concerned. They would receive their tasks from the civil authority, but in order to transform these directives into militarily relevant orders, a military superior is required.

Paragraphs 2 and 3 of Article 35 of the Basic Law go significantly beyond technical and logistic support. They allow the police forces of an affected state to receive support from the police forces of other states, from the federal police (Bundespolizei), ${ }^{11}$ or, in extremis, from the armed forces. This type of support could include law enforcement activities being carried out by the armed forces, such as the protection of critical infrastructure or the protection of disaster areas against looting. But the military support would always be under the direction of the regional police force, and the rules of such an engagement would be the laws of the relevant state. Moreover, this law en-

9 This fact is supposed to be the reason why the German armed forces never accepted any regular responsibility for disaster relief efforts. During the Cold War, they always had to be prepared to become 100 percent engaged in defense of the German territory. This is an argument that is no longer valid under the new strategic conditions.

See, for example, Schmidt-Bleibtreu, Kommentar zum Grundgesetz; Dr. Phillip Kunig, Grundgesetz - Kommentar, 5th edition, Vol. 2, section on Article 35; or Dr. Klaus Müller, Grundgesetz - Taschenkommentar für Studium und Praxis, 11th edition (Cologne: Heymanns Taschenkommentare, Carl Heymanns Verlag, 2002).

11 The former Border Guard Police (Bundesgrenzschutz). 
forcement support is clearly limited to the cases of natural disasters and catastrophic accidents.

As this regulation gives the federal government an opening to exert powerful influence against the sovereignty of the states, this kind of MACA has to be stopped immediately once the situation is stabilized again, or it is requested by the senate. And there is another strict limitation on the use of the armed forces for law enforcement purposes. Legal scholars are quite unanimous (so far) that the engagement of the armed forces in these cases is only legitimate, when the disaster or catastrophic accident has already happened, or is about to. Any engagement to prevent an anticipated or generic threat from happening is prohibited. Allowing participation in preventative actions, however, is the key to permitting military support of homeland security against any terrorist threat.

In summary, the legal framework of MACA allows the Bundeswehr to provide technical and logistic support to the greatest extent possible, even for purposes of prevention. However, it is primarily intended for exceptional cases, rather than predictable events. Military assistance in law enforcement affairs is intentionally kept very restrictive, and does not allow the German armed forces to participate in preventive measures.

This very restrictive attitude became evident in the recent discussions about the new Air Policing Act. After the September 11 disaster in New York, and an incident involving an uncontrolled sports plane in Frankfurt, the German government prepared a bill to close an important loophole in the legal system. It had become evident that the extant German law would have made it impossible to stop a civilian airplane from being used as a weapon. Fortunately, the airspace over Germany is a federal responsibility, and does not fall under the states' sovereignty. ${ }^{12}$ Although this was one less administrative hurdle to clear, the bill was still very difficult to prepare, and the issues are not all yet resolved.

The reasons for the legal difficulties are that, first, the relevant aircraft is not a military aircraft, and neither the (potential) terrorists nor the passengers are combatants. Thus, dealing with such an aircraft should be the responsibility of the police forces. The police, however, have no means of dealing with such an aircraft, and nobody intends to provide the Federal Police with fighter jets or anti-aircraft weapons for such an unlikely scenario. Therefore, military support was requested under MACA. But, as it is a permanent threat and needs permanent readiness to react, it would require a permanent transfer of a mission from the police to the armed forces. That is in conflict with the law that details the modalities of administration assistance. Second, another law forbids the military to use firearms against unarmed groups of civilians if it cannot be ruled out that children might be hit. ${ }^{13}$

12 The airspace above Germany only recently came under federal responsibility, because until 1992 it was under international (NATO) control.

13 Gesetz über die Anwendung von unmittelbarem Zwang durch Angehörige der Bundeswehr (UZwGBw) $\S 15$ and 16 (Federal Law about the Exercising of Violence by Members of the Bundeswehr). 
Even though the Air Policing Act became effective in January 2005, when it was signed by the president, it is not sure whether it will remain in effect. The president had serious concerns, and therefore applied for a revision by the Court of Constitution.

Another area of concern is the area of special security events. Germany is preparing to host the soccer World Cup in 2006. Currently, there is no possibility of involving the German armed forces in protective and preventative activities. General patrolling, as we saw during the Olympic Games 2004 in Athens, and see every day in France, is not possible in Germany under present legal conditions.

\section{Command and Control of the German Armed Forces in Homeland Security Engagements}

Everything concerning security in Germany is still based on the tradition of defending German territory that is left over from centuries past. This general basis was even reinforced by the unique security situation that was in place during the Cold War years. According to this vision of the military's responsibility, the protection of civilians and civil property has always been the responsibility of the police forces, and is under the control of the Ministry of the Interior and the Ministries of the Interior of the Bundesländer. This distribution of responsibility was widely accepted, as it was evident to everybody that the armed forces could not be spared for that simple purpose. All of the military's resources had to be reserved to (potentially) fight against enemy combatants. Even in the combat zone in the event of war it would have been the responsibility of the police to protect civilians against attacks by non-combatants.

In the combat zone, the main defense operation against hostile combatants would have been managed by the Field Army, in combination with NATO. Outside the combat zone, it would have been up to the Territorial Army to organize support for the Field Amy and to conduct operations against airborne combatants or hostile troops that had broken through the front lines. For that purpose, each civil district had a Military District Command HQ, ${ }^{14}$ and each county had a County Command HQ. ${ }^{15}$ Above that level, there were six Regional Commands HQ ${ }^{16}$ and two Territorial Commands HQ. ${ }^{17}$

To carry out territorial defense in the rear of the combat zone against combatants, many homeland protection forces were put in place. These constituted the Territorial Army, and consisted almost entirely of reservists. After the end of the Cold War, these forces were significantly reduced, but even today there are approximately 75,000 reservists still employed in such home defense companies, battalions, and brigades.

The territorial command structure was mainly designed to organize support for the field forces from civil sources, and to control defensive operations against the threat from combatants in the rear of the main deployed force. Beyond that, this command

14 Verteidigungskreis Kommando (VKK).

15 Verteidigungsbezirks Kommando (VBK).

16 Wehrbereichskommando (WBK).

17 Territorial Kommando (TerrKdo). 
structure was also used in peacetime to manage civil-military coordination and Military Assistance to Civil Authorities (MACA) efforts in cases of disaster relief.

After the end of the Cold War, the territorial command structure was cut down somewhat, but the organization still remained primarily built around the requirements of territorial homeland defense. It also retained responsibility for managing MACA and disaster relief operations. This concept remained in effect until March 2003.

At that time, the Minister of Defense released a new security doctrine, which stated in essence: ${ }^{18}$

- In the future, territorial defense would be extremely unlikely to be necessary in Germany, and there would be no longer a justification to commit resources to that purpose;

- The most likely missions for the armed forces would be operations outside of Germany, and all resources should be concentrated on this type of operations.

The new doctrine stated explicitly that permanent organizations designed for territorial defense alone would no longer be justified. In consequence, the existing territorial defense organization, the territorial command structure, and the homeland defense forces came in for a stringent review in order to find out what roles would remain for them aside from territorial defense.

The review confirmed that there is still a need for a body to manage civil-military coordination and cooperation with the civil authorities of districts, counties, and states, and that there is still a substantial requirement for the armed forces to provide MACA, especially for disaster relief. The latter role was given even more importance because of the challenges posed by the international terrorism.

To meet these residual requirements, a new structure was developed in order to reduce manpower requirements, but to continue providing at least the same amount of assistance to civil authorities as before. The cornerstones of this new structure, which has been operating on a pilot basis since October 2004 in three states, are outlined below.

For each district (Kreis) - being the lowest level of disaster relief authority - there will be one staff officer of the reserve as a permanent representative of the armed forces for civil-military cooperation and coordination. ${ }^{19} \mathrm{He} /$ she will also support the public administration in contingency planning for disaster relief plans. The staff officer is supported by a section of approximately ten reservists (three officers, three senior NCOs, and four junior NCOs), all volunteers for the posts and available for shift duty. Together they form the military section of the district's crisis management headquarters, which forms in cases of real disasters and for exercises. All of the reservists should be residents of that particular district. They should also have experience in

18 Bundesministerium der Verteidigung, Verteidigungspolitische Richtlinien für den Geschäftsbereich des Bundesministerium der Verteidigung (Berlin, 21 March 2003).

19 He will be called the Beauftragter der Bundeswehr für die Zivil-Militärische Zusammenarbeit (BeaBwZMZ) which means "representative of the Bundeswehr for civil-military cooperation." 
many exercises in reserve positions with the active military. They might also be retired professional soldiers. This military HQ element will be called the KVK (Kreis Verbindungs Kommando), or District Liaison Command. Their job will be to provide general advice on military matters to the local civil authority responsible for disaster management. They have to consider options for military support and prepare, coordinate, and support the deployment of the armed forces within their district. The KVK will not be equipped or authorized to exercise tactical control over a military engagement in their district. Instead, they will be part of the civil authority responsible for the management of disaster relief efforts, and will advise, coordinate, plan, and provide direction.

On the next higher administrative level, the county (Regierungsbezirk), a colonel of the reserve will be appointed, again along with approximately ten reservists to form a BVK (Bezirks Verbindungs Kommando, or County Liaison Command), to perform the same role at the county level. In total there will be around $470 \mathrm{KVKs}$ and BVKs throughout the country, with approximately 4700 voluntary reservists.

On the level of each state there will be a permanent headquarters, formed with roughly fifty active-duty soldiers, called Landeskommando (LKdo, or State Command). The commander of an LKdo unit will be the official delegate of the armed forces to the state, and will coordinate civil-military cooperation at that level. In cases of disaster, the state command forms a military branch in the state's crisis management $\mathrm{HQ}$, and the commander of the LKdo unit for that state becomes the military advisor of the president of the state. In principle, the system operates on the state level in the same way as described above for the lower levels, but in a permanent way and with active-duty soldiers instead of reservists. In addition, the commander of a State Command is authorized to form an initial ad hoc disaster battle group from troops stationed in his state and make it available for that mission. He will also appoint the first tactical commander and establish the field headquarters for this battle group. However, as with the $\mathrm{KVK}$ and the $\mathrm{BVK}$, neither he nor his branch is equipped for military command, control, and communication (C3) purposes, so the military field headquarters will have to establish communications in the civil HQ.

The necessary military type of command and control for the soldiers engaged in disaster relief missions will be established by the four Regional Command headquarters, called Wehrbereichskommandos (WBK). They form the next level of the territorial command structure. Today these Regional Commands, which during the Cold War were at the divisional level of military homeland defense, have become the primary divisional level for the recently formed new arm, the Joint Support Service (Streitkräftebasis, or SKB). ${ }^{20}$ It will remain the job of the Regional Commands to establish regular military $\mathrm{C} 3$ capabilities, and provide military logistics and sustainability for the forces deployed on missions related to homeland security. The commands will do this mainly

${ }^{20}$ All joint support functions were put together and now form the Joint Support Service (Streitkräftebasis). 
by drawing on resources from their area of responsibility, which could comprise up to five Bundesländer.

If military support from other areas of Germany were required, it would be the responsibility of the Armed Forces Support Command (Streitkräfte Unterstützungs Kommando, or SKUKdo) to manage that. They are the highest command level of the Joint Support Service, and wholly responsible for management of the armed forces' involvement in MACA and disaster relief activities. They would report directly to the Ministry of Defense.

The old (but still valid) C3 structure for the engagement of German forces in MACA, the new structure, and the future command and control (C2) relationships are all depicted below. The main differences are that the new command structure is more closely adapted to the civil administration. Civil-military cooperation is now their main task, having replaced homeland defense operations. And the liaison job on the county and district levels is no longer done by active-duty soldiers, but by reservists. These reservists will find themselves occupying a new status. They will no longer be legitimized only by the state of defense. Instead, they will cover a part-time but permanent military task in peacetime. For Germany, that is a revolutionary change that will take some time to be accepted. The greatest progress for the civil administration is that they will now have a dedicated permanent military element in their crisis management headquarters.

The first results from the trial phase of the new structure, as well as two major disaster relief exercises staged in 2004, have already proved that the new approach is very much welcomed by the civil administration. It seems that it is even preferable to the existing system. The intention is to complete the change to the new system and structure by 2006 .

\section{International Terrorism: A Military Threat?}

Immediately after the terrorist attacks of September 11, Germany started reviewing the new threat and discussing how to protect the country against it. After the end of the Cold War, Germany had significantly reduced all preparatory measures for the protection of the civilian population against war-related threats. Germany no longer faced the risk of becoming the battlefield for the Third World War. In particular, the Ministry of the Interior, with its responsibility for the management of the protection of the civil population from war-related damages, had completely marginalized its management capacity and the related resources. Exercises, both for the military and other branches of the government, had been stopped. Capacities had been reduced to just meet the requirements of natural or industrial disasters. And the management of these cases was now completely under the responsibility of the Bundesländer.

With the new type of threat posed by international terrorism, and the potential for mass casualties, it became evident that there might not be sufficient capacities remaining to adequately address the new security situation. In opposition to this need, the military capacities related to territorial defense were still kept substantially unchanged, but were under strict review because of the change in defense policy. So the actual dis- 
cussion was very much driven by the questions, "Who should have to pay for the necessary restoration of capabilities?" and "Why not give more responsibility to the Armed Forces? They still have enough capabilities." The discussion is ongoing. The answer will depend very much on the political decision that is made about how to categorize this new threat.

Germany has had some experience with terrorism in the 1970s, but this was internal German terrorism (led by such groups as the Red Army Faction), directed mainly against the German political system by attacks on civilians of major political and economic importance. All these terrorists were Germans. Besides killing individuals, the damage was rather limited and local, so there was no doubt that the states and their police forces were responsible for dealing with these incidents.

But the threat itself was not a regional problem, but a national one. Therefore, prevention measures and prosecution needed to be coordinated at the national level by the federal Ministry of the Interior. And even though the terrorists themselves wanted to be seen as warriors and treated as combatants, nobody was seriously of the opinion that these situations might reach the scale of "defense" in its legal meaning. Thus it was never thought to support the fight against this terrorism with military means, or to place it under the responsibility of the Ministry of Defense (MoD).

Today, the threat of international terrorism is different, and so are the resources needed to fight it. The damage can reach dimensions that in the past it was only possible to achieve through full-fledged warfare. The threat in general is organized from outside Germany, but the people executing it might live in Germany. The threat appears to be against our society in total, and against the lifestyle and culture of Western civilization in general. The terrorists do not fight against other combatants, but against the citizenry as a whole. Thus it remains - using our traditional legal tools - a matter for the police, with the states and the federal Ministry of the Interior sharing responsibility. Even the responsibility for disaster relief management would stay with the states and the local authorities. Again, the armed forces could not be employed in preventative measures, and can only act in a supporting role.

But more and more political and legal experts are beginning to change their minds. There is a growing body of opinion in Germany that the fight against international terrorism has to be seen as a new kind of war, because the intentions of the terrorists and the extent of the damage they can bring about equate to war.

The perception of the fight against terrorism as a kind of war would have farreaching consequences, and the responsibility for addressing it could be completely inverted. If this view were to prevail, the Minister of Defense would be in charge of the entire effort, and it would be the military budget that paid for preparatory and preventive activities. But even with such a change of perception, the responsibility for the protection of civil society would remain with the Minister of the Interior, like it was in the time of the Cold War. The armed forces would only be authorized to fight again this new type of combatant, the terrorist. Being no better prepared for such a war than the police are at this point, the armed forces do not find the idea terribly appealing. They see the danger that they might be given that responsibility without warning. On the occasion of a major terrorist attack, a state of tension could easily be declared by 
the parliament with a two-thirds majority. Having shown the complicated and sensitive relationship between the government and the states in Germany, and the strict separation of roles for the police and the military, the declaration of the state of defense would at least make the task of the management of prevention and damage much clearer.

This solution is not so unlikely as it sounds. A much greater interpretive leap regarding how the armed forces might be used was made when the Court of Constitution - which is responsible for the interpretation of the Basic Law-in connection with the first German military missions abroad accepted the premise that the "defense of Germany" could also take place outside NATO territory. Keeping this in mind, it seems much less difficult to allow the threat from international terrorism to trigger the declaration of a state of defense.

However, under the given legal framework for the state of defense to be declared, the German armed forces would only be authorized to manage the situation and to fight against combatants - in this case, the terrorists. The management of the protection of civilians and their vital networks would remain the responsibility of the Ministries of the Interior of the republic and the states.

\section{The Attitude of the German Armed Forces towards Homeland Security Engagements}

The Bundeswehr has not been used to having any serious obligations in homeland security affairs. As mentioned before, the defense of German territory against traditional combatants was always its first priority during the period of the Cold War. For that purpose, everyone and everything had to be maintained at a constant state of preparedness. Under these conditions, no one expected the armed forces to be officially engaged in relief efforts following natural disasters or catastrophic accidents. Of course, whenever such an event did occur, the military proved to be the only organization capable of providing the necessary management skills and capabilities to solve the problem. The generally accepted practice was that the armed forces would never guarantee the ability to provide any capabilities for disaster relief, but in cases when disasters happened they would help with all their available means and capabilities. That is what they proved to be capable of on many occasions.

After the end of the Cold War, the state's capabilities for civil protection in wartime were drastically reduced. Now, under the specter of international terrorism, many of them are required again. Therefore, the states, being responsible for disaster relief management, want more of a guarantee that the Bundeswehr will become engaged. That would help the states to save resources. Why should they set aside capabilities for a rather unlikely eventuality if these capabilities were permanently available within the armed forces?

The armed forces, on the other hand, have lost their main role of the territorial defense of Germany, under which 100 percent of their capabilities would have been engaged. And, following the official doctrine, no more than 40 percent of the armed forces would ever be engaged on missions abroad in the future. However, the 
Bundeswehr continues to stick with their traditional doctrine of not participating in disaster relief efforts on a more calculable basis. They refuse to officially declare any of their abilities and capabilities to be consistently available for the support of civil disaster relief. The following reasons could account for this position.

The doctrines from the Cold War era are still ingrained, even though the situation has changed completely. Nobody is interested in examining the validity of the doctrine that is an artifact from those days. This can be seen in many cases. To some extent, it applies to many areas of the Basic Law, which was created under the influence of the Second World War and the beginning of the Cold War.

The Armed Forces do not want to be slowly drawn into having responsibility for disaster relief, which legally is entirely the responsibility of the Bundesländer. They are concerned that they would no longer be free to make deployment decisions. The states are thought to be interested only in order to save money, and to be unwilling to ever give something in exchange.

Even after the end of the Cold War, territorial defense remained the main task of the Germany military. ${ }^{21}$ As a result, it was not possible to convert all resources to the preparation for the much more likely cases of operations outside Germany, for which a completely different structure and equipment is needed. The new defense doctrine from 2002 finally opened the way to getting rid of all the ballast remaining from the territorial defense obligation. Now the planners are concerned that, via the threat of international terrorism, the armed forces would again be drawn back into territorial-defensetype obligations, with no increased budget for this additional task. All in all, the armed forces are still very reluctant to provide a higher level of engagement in anti-terrorism activities.

\section{Options for the Way Ahead}

Immediately after September 11, 2001, discussions began regarding what options Germany would have if anything similar to the attacks on New York and Washington should occur in Germany. Scenarios were examined to consider what further options could be chosen by international terrorists in order to shock the sensitive, technologydependent civilization of German and European society. The United States took it as a military challenge, reacted accordingly, and persuaded NATO to treat it as a military affair as well. However, Germany still views this threat from the traditional, criminal perspective. The states are responsible for the prevention of criminal activity (including - under this view - terrorism), and damage control and management is within the portfolios of the Ministries of Interior of the affected states and the federal Ministry of the Interior. The German armed forces play only a supportive role for damage man-

21 While other European nations quickly changed their national security policies, Germany left it substantially unchanged for a while. Germany was very much diverted by the problems of German reunification, among which the integration/dissolution of the armed forces of the former DDR was one of the most complicated. 
agement efforts, if they are not committed to defense missions. They are not allowed to participate in prevention measures, apart from providing technical support.

Following the events of September 11, it was quite clear that Germany's existing "toolbox" would provide no tool to prevent a terrorist attack under the given legal conditions. It was also clear that only the Bundeswehr had the capabilities to respond to the threat of a civilian passenger airplane used as a weapon. The complete helplessness of the German administration in such a case became evident again in January 2003, when a small leisure aircraft flew around the skyscrapers of Frankfurt's banking area unabated. Even though this was an event of minor importance, because the small plane could have done no serious harm to the multi-story buildings, it did happen, and gave the final motivation to close an evident loophole in the German legal system. Immediately a bill was prepared that would give the Secretary of Defense the authority to order such an airplane shot down by fighter aircraft of the air force as a "last resort." The law, called the "Air Security Act" (Luftsicherheitsgesetz), was to be based on the established interpretation of the Basic Law, Article 35 sentences 2 and 3, which deal with administrative assistance by the armed forces in a law-enforcement situation, as described above. But from the beginning, many constitutional scholars did not feel comfortable with this solution. Most of the experts were of the same opinion as Christof Gramm, who argued that the Basic Law in its present version would not allow the permanent delegation of authority to the armed forces to counter a foreseeable and permanent threat. ${ }^{22}$ Instead, the amendment of the Basic Law would be required. Others, like the Member of Parliament Dieter Wiefelspütz, are of the opinion that everything would fit easily within the existing framework of the Basic Law, and that at present no amendments would be needed. ${ }^{23}$

The Air Security Act was finally signed by the German president in January 2005, effective as of 26 January. The president released the bill with the caveat that it should be revised by the Court of Constitution, since he was concerned about the legality of the act, especially because of the need to consider the certain death of innocent civilian victims in the airplane against the possible death of victims on the ground. This eventuality, being a completely new and unique situation, was not covered by the extant legal framework.

In addition, the political opposition has announced that they would bring this act to the federal Court of Constitution to have it reviewed. Whether the act will remain valid under these conditions is uncertain. A similar act is in preparation, dealing with the response to terrorist actions on sea and land, especially in the vicinity of harbors.

More and more scholars and politicians have come to the conclusion that this type of terrorism is a new general type of external threat, and that the armed forces should be responsible for providing more calculable protection and leading prevention efforts,

22 Dr. Christoph Gramm, "Bundeswehr als Luftpolizei: Aufgabenzuwachs ohne Verfassungsänderung?" Neue Zeitschrift für Wehrrecht (2003): 89-101.

23 Dieter Wiefelspütz, "Sicherheit vor den Gefahren des Terrorismus durch den Einsatz der Streitkräfte," Neue Zeitschrift für Wehrrecht (2003): 45-65. 
just as they did in the past for traditional homeland defense. ${ }^{24}$ The chances that this perspective will meet with wider acceptance seem relatively good. Some states would reap a benefit if this were the case, because the resources used to fight terrorism would have to be taken from federal sources, instead of from the individual states. That, of course, is not in the interest of the federal government; the states as well as the Ministry of Interior, being the entities traditionally responsible for the protection of the civilian population in peacetime and wartime, would have dramatically reduced their level of expenditure for this increasingly important activity. To close the gaps that were identified in the meantime will require a great deal of money.

Above all else, the legal framework for declaring a state of defense only allows the military to use their abilities to defeat these new types of combatants and to be responsible for the protection of the homeland against this threat. The protection of civilians, however - the so-called Civil Defense, established during the Cold War-would remain the responsibility of the Ministry of the Interior. ${ }^{25}$ To fall back into such a traditional mode seems attractive to many people, because then many patterns and methods from that period could still be used.

I am quite confident, however, that in case of a disaster, such as the train bombings in Madrid on 11 March 2003, the German Parliament would decide to declare a state of defense. That would be the easiest way to come to a clear distribution of roles and responsibilities. It was much more difficult for the German Parliament to change the interpretation of defense from the traditional territorial focus to a global view than it will be to declare international terrorists to be combatants, and their method of asymmetric attacks on German territory as a new form of war.

But, to be honest, such a quick solution would only go half way. Most of the capabilities needed to fight terrorism in Germany are more of a non-military character. This fight begins with an investigation of how to identify the enemy and his intentions; this approach is quite different from the military method of reconnaissance, be it inside or outside of the home territory. It ends with the analysis of the targets. For terrorists, the main target is not the combatant, but unprotected civilians and the insecure civilian infrastructure.

24 Christian Lutze, "Abwehr terroristischer Angriffe als Verteidigungsaufgabe," Neue Zeitschrift für Wehrrecht (2003): 101-15; and Martin Hochhut, "Militärische Bundesintervention bei inländischem Terrorakt," Neue Zeitschrift für Wehrrecht (2003): 154-67.

25 See the German Society for Military Law and Humanitarian Law, "Civilians and the Military," Report submitted to the 12th Congress of the International Society for Military Law and Law of War (Brussels: May 1991); Alexander Poretschkin, "Zivilverteidigung als Verfassungsauftrag," Ph.D. Diss. im Fachbereich Sozialwissenschaften der Universität der Bundeswehr (1990); and Bundesminister des Innern, Bundesminister der Verteidigung, "Rahmmenrichtlinien für die Gesamtverteidigung" (Bonn: 10 January 1989), BMI-KN7731800-51; BMVg-VR II 6/FüS VI 5-31-02-04, GMB1 1989, 107. In addition, see Deutscher Bundestag, Zivilschutzgesetzt (ZSG), (25 March 1997); Bundesgesetzblatt I, 726 (status 27 April 2004). 
So a separate approach has to be developed in order to meet the challenges of this new situation. No doubt such an approach would lead to even more obligations for the German armed forces than they envision at present. The Bundeswehr is in a kind of euphoric phase of transformation to an expeditionary army. But German society still wants them to feel more responsible for direct homeland security, defending the nation inside Germany rather than in Afghanistan.

So, a clear way ahead cannot be predicted.

\section{Conclusion}

The existing German options to involve the military in homeland security affairs can be put quite simply. In case of an attack by traditional combatants, all necessary actions to meet this challenge can be taken by - and are the responsibility of - the armed forces. This includes all actions to prevent such an attack from happening.

However, when the possible attackers are not of the traditional combatant type covered by the Geneva Convention, the situation becomes more complicated. The legal framework for the scope of the activities of the Bundeswehr is clearly and strictly laid down in the German Constitution, the Basic Law. There is little leeway given for interpretation in the Basic Law, and this document, unlike many other constitutions, is effective for jurisdiction. The German Basic Law was developed with the clear intention to minimize the possibilities of the misuse of central political and military power to the greatest extent possible. The disadvantages in effectiveness that this approach implies were taken into account, and were in fact seen as helping to optimize that intention. Changes to the Basic Law have only been made in response to imperative challenges, never in order to improve the administrative management of the republic. The reestablishment of the German armed forces in 1955 is one example of such an imperative challenge. And the threat by the international terrorism might be another. The authors of the Basic Law did not foresee this kind of threat; therefore, there is no suitable article in the constitution that outlines how the German state is to respond to this new threat to its security. In spite of that, the existing legal framework allows a wide variety of possibilities that may be helpful in the new security environment. The armed forces might provide technical support, and even tools to support prevention efforts. But so far there is a common understanding that the participation of soldiers in actions of law enforcement to prevent terrorism-related disasters from happening is prohibited.

As soon as an attack has happened or is about to happen, the military might be engaged, even in a law enforcement role. However, even in this case, they may not act in a military manner, but only under the legal conditions of the regional police forces.

At this point it remains unclear who should feel responsible for taking preventive measures against an attack by international terrorists in the future. There is still no legal permission for the German armed forces to participate in preventive management or to support prevention management efforts by engaging their special capabilities, even if they are the only entity with the appropriate means to counter the threat. The controversial discussion about the Air Security Act in January 2005, which would al- 
low a German military aircraft to ultimately destroy a civil aircraft that has been captured by terrorists, highlighted this situation very clearly.

But, following German tradition, this gap will be closed. The timing of this will depend on the perception of how urgent the threat is felt to be. Hopefully, it will not be the day after the first massive terrorist attack has happened in Germany. The first initiatives have been taken, not only by legal experts, but also by some states and political parties. They all want the military to bear a greater level of responsibility for meeting these new challenges.

But the Bundeswehr is not pressing in that direction. On the one hand, they are very positive about promising any support that is legally permitted in case such a catastrophe occurs. On the other hand, they do not want to be held accountable for all such cases in the future. Now that they finally have started the difficult process of transformation to gain expeditionary capabilities, they especially do not want to divide their very limited budget to address this issue. But all ongoing discussions go into the same direction: this form of homeland security should no longer be only an obligation in subsidiarity, but should become a core function of the German armed forces. Terrorism is a new form of external threat, waged by a new form of combatant. And the German armed forces are well advised not to remain too reluctant. The German people will fail to understand - on both an emotional and intellectual level - why German soldiers should prevent Serbs from being attacked by Albanians in Kosovo, but should not defend Germans from being attacked by international terrorists. 
THE QUARTERLY JOURNAL

\section{Bibliography}

Gramm, Dr. Christoph. "Bundeswehr als Luftpolizei: Aufgabenzuwachs ohne Verfassungsänderung?" Neue Zeitschrift für Wehrrecht (2003): 89-101.

Hochhut, Martin. "Militärische Bundesintervention bei inländischem Terrorakt." Neue Zeitschrift für Wehrrecht (2003): 154-67.

Lutze, Christian. "Abwehr terroristischer Angriffe als Verteidigungsaufgabe." Neue Zeitschrift für Wehrrecht (2003): 105-115.

Müller, Dr. Klaus. Grundgesetz - Taschenkommentar für Studium und Praxis. 11th ed. Cologne: Heymanns Taschenkommentare, Carl Heymanns Verlag, 2002.

Poretschkin, Alexander. Zivilverteidigung als Verfassungsauftrag., 1990.

Richtlinie über den Einsatz von Rettungsmitteln der Bundeswehr im Rahmen des zivilen Rettungswesens. Bundesministerium der Verteidigung, Ministerialblatt, 1988.

Schmidt-Bleibtreu, Bruno. Kommentar zum Grundgesetz. 10th ed. Verlag Luchterhand, 2001.

Umbach, Dieter C.. Grundgesetz, Mitarbeiterkommentar und Handbuch. Berlin: Deutsche Bibliothek, 2001.

Wiefelspütz, Dieter. "Sicherheit vor den Gefahren des Terrorismus durch den Einsatz der Streitkräfte." Neue Zeitschrift für Wehrrecht (2003): 45-65. 